\title{
A future-oriented approach to company annual reporting in South Africa: management views
}

\author{
Elmarie Saenger \\ Department of Accounting, University of South Africa, P.O. Box 392, Pretoria 0001, Republic of South Africa
}

Received July 1992, accepted April 1993

\begin{abstract}
A future-oriented approach to company annual reporting is examined as perceived by selected company managements in South Africa. In the article the focus falls on the managers' opinion of three aspects important to the issue of futureoriented reporting, namely the need for publishing future-oriented information in company annual reports, the type of information to be disclosed and the manner in which it should be presented in company annual reports, and the need for public accountant auditing of the information. As this type of reporting is relatively new in South Africa, an attempt is made to contribute to a better understanding of the subject and to provide some guidance as to its future development.
\end{abstract}

'n Toekomsgeoriënteerde benadering tot maatskappyverslagdoening word ondersoek soos deur geselekteerde maatskappybestuurders in Suid-Afrika waargeneem. In die artikel val die fokus op die bestuurders se houding jeens drie belangrike aspekte met betrekking tot die kwessie van toekomsgeoriënteerde verslagdoening, naamlik die noodsaaklikheid om toekomsgeoriënteerde inligting in maatskappyjaarverslae te openbaar, die tipe inligting wat gepubliseer behoort te word en die wyse waarop dit in maatskappyjaarverslae aangebied behoort te word, en die behoefte aan openbare rekenmeesterouditering van die inligting. Aangesien hierdie tipe verslagdoening redelik nuut in Suid-Afrika is, word met die artikel gepoog om tot 'n beter begrip van die onderwerp by te dra en om 'n mate van leiding te gee in soverre dit die toekomstige ontwikkeling daarvan betref.

\section{Introduction}

Traditionally, company annual reports have, in line with their stewardship function, presented only historical financial information. From a decision-making point of view, however, the disclosure of both historical and prospective information is important as decisions cannot only be based on appraisals of past and current company performance and position. Decisions should also be contingent upon assessments of future company performance and position as most decisions are inherently future oriented, that is, they are based on a prognosis of future events (Lee, 1981: 99). ACknowledgement of this premise has over the past two decades resulted in a gradual extension of the boundaries of traditional company annual reporting to include what is generally known as a future-oriented or prospective reporting approach. This approach, which essentially comprises the reporting (either by means of management projections, predictions or forecasts) of information relating to the future of a company, has attracted varying attention in various countries. This has resulted in empirical research to determine a basis for issuing pronouncements on the disclosure and audit of the information. (For example, refer to Ferris \& McDonald, 1982; AICPA, 1985, 1986; CICA, 1989a, 1989b; and Tonkin, 1989.)

\section{Problem definition}

In South Africa the issue of future-oriented financial reporting is relatively new. Although it is practised to some extent by certain companies, very limited empirical investigation of the approach has been undertaken. In addition, the accounting profession in South Africa has to date issued an audit and accounting guideline on only one component of this type of reporting, namely, profit forecasts (SAICA, 1989). This guideline does not carry the same authority as Statements on Auditing Standards or Statements of Generally Accepted Accounting Practice. In the light of overseas experience and experimentation with the subject, this study, which forms part of a wider investigation of the issue, was undertaken in an attempt to help fill the gap in the South African literature, to increase understanding of the issue and its implications for company annual reporting, and to provide some guidance in so far as its future development is concerned.

\section{Methodology}

To implement the study, survey research, and in particular postal opinion research, was used.

The 1989 Financial Mail Top 100 companies were selected as target group and a questionnaire was sent to the financial manager of each of these companies. To obtain more detail on the managers' responses, the companies were classified according to their field of activity.

The questionnaire was compiled and distributed with the assistance of the Bureau of Market Research at the University of South Africa. A response rate of $81 \%$ was obtained.

The responses were processed by the Department of Computer Services at the University of South Africa in cooperation with the Bureau of Market Research. The all-purpose Statistical Analysis System (SAS) was used for the analysis of the data.

\section{Findings}

Need for publishing future-oriented information in company annual reports

Analysis of the responses to the question posed in this connection, reveals that the respondents were divided more or less fifty-fifty on the issue; $49 \%$ favoured the disclosure of future-oriented information, while $51 \%$ opposed the practice (refer to Appendix 1).

The results furthermore show that the field of activity in which the respective companies are engaged had a decisive influence on the reported viewpoints. 
To get a more complete view of the respondents' attitudes, the reasons for their respective points of view were also considered.

Appendix 2 shows that the respondents regard the following reasons as the most important reasons why companies should disclose future-oriented information:

- To provide information useful in making investment decisions.

- To disseminate the information on an equal basis to all interested parties.

- Company management is in the best position to provide the information.

The field of activity in which the companies are engaged had very little influence on this ranking of reasons.

In so far as the most important reasons against the disclosure of future-oriented information are concerned, the respondents indicated the following (refer to Appendix 3):

- The doubtul reliability of the information.

- Competitive disadvantage for disclosing companies.

- Possible management manipulation of the information.

This analysis is based on the total responses of the participants as the field of activity in which their companies are engaged resulted in their individual points of view deviating to some extent from the overall ranking.

\section{Presentation of future-oriented information in company} annual reports

This part of the research, the results of which are summarized in Appendix 4, sought to determine the attitudes of the respondents (who supported the disclosure of the information) towards the aspects discussed below.

\section{Format and form of disclosure}

With regard to the general format for the presentation of future-oriented information, the results reveal majority support for the selective (summarized) disclosure of the information. Field of activity apparently had little influence on the opinions of the respondents. This preference probably reflects the willingness of company managements to present only the minimum statutory information and emphasizes the need expressed in overseas countries to distinguish between historical and future-oriented statements.

To determine the preferred content of the chosen format of disclosure, respondents were asked to identify the items of information they would like to have forecasted. The respondents agreed that future sales, future capital expenditure and future earnings per share should be disclosed. It is interesting to note that with the exception of the construction companies and the manufacturing/industrial companies, the respondents gave equal support to these items of information.

The respondents were furthermore of the opinion that only narrative comments should be made on future sales and future earnings per share, while both narrative comments and quantified amounts should be provided on future capital expenditure. Exceptions to this pattern include the point of view of the construction companies, the mining, financial and insurance, and printing and publishing companies and the manufacturing/industrial companies.
The results pertaining to the form to be used for the presentation of quantified future-oriented information, show that although the companies as a group indicated a slight preference for a range form of disclosure, the construction companies and the hotels, beverages and leisure companies preferred a single figure form, while the retail and wholesale companies and the mining, financial and insurance, and printing and publishing companies were ambivalent on both forms of disclosure. When considering these results, cognisance must be taken of the high percentage of respondents who gave no answer to this question. A possible reason for this could be the fear to commit to either single figures or ranges in view of the fact that single figures could signal precision, while users of the information could place unwarranted confidence in the limits of the ranges.

\section{Period to be covered by the information}

Appendix 4 shows that the respondents, with the exception of the mining, financial and insurance, and printing and publishing companies who were ambivalent on a maximum period of 12 months and 24 months, felt that future-oriented information should cover a maximum period of 12 months. The respondents most probably viewed this period as maximum because of doubt about the possible reliability of future-oriented information extending beyond this period.

\section{Importance of disclosing underlying assumptions}

The respondents overwhelmingly felt that all three categories of assumptions indicated in the questionnaire should be disclosed with future-oriented information. By acknowledging the importance of underlying assumptions, the respondents obviously agree with proponents in overseas countries that the disclosure of assumptions would enhance the usefulness of future-oriented information for decisionmaking, reduce the possibility of users placing undue reliance on the information and reduce criticism and the legal liability of company managements should the information differ significantly from actual results. Consequently, there can be concurred with Howell (1987: 51) that the disclosure of underlying assumptions would be an essential component of any future-oriented policy if the needs of interested parties are to be met.

\section{Updating and revision of the information}

From Appendix 4 it is apparent that there is wide agreement that future-oriented information should be updated and revised. By coming out so strongly in favour of the issue, the respondents obviously support the argument advanced in overseas countries that the updating and revision of futureoriented information will ensure that the information remains relevant for decision-making and that such a practice will educate users in the uncertainty of the information. In so far as the frequency of updating and revision is concerned, the results show that although the companies as a group favoured a half-yearty frequence, the retail and wholesale companies and the hotels, beverages and leisure companies preferred annual revisions, while the mining, financial and insurance, and printing and publishing companies were ambivalent on the two periods of revision. 
Need for public accountant audit of future-oriented information published in company annual reports

The last part of the research examined whether or not a need exists for extending the public accountant's audit duty to include published future-oriented information.

To determine this need, the respondents who supported the disclosure of the information were asked to indicate whether or not they agreed with the issue. A majority of the respondents were against public accountant audit of the information (refer to Appendix 5). More than $60 \%$ of the respondents rejected the issue, while the company active in the transpon field supported it.

As a next step, the survey sought to establish the reasons for the answers provided to the previous question.

According to Appendix 6,79\% of the respondents regarded the improvement of the credibility and usefulness of future-oriented information as primary reason for public accountant audit of the information. This was followed by the following reasons: the prevention of purposely overstated or understated information (43\%); and the competence of public accountants to examine and report on the information (29\%).

Field of activity had an influence on these results in that only the manufacturing/industrial companies agreed with the above ranking.

In so far as the reasons against public accountant audit of future-oriented information are concerned, Appendix 7 shows that $58 \%$ of the respondents regarded undue user faith in and reliance on the accuracy of the information as the most important reason.

Other reasons identified by the respondents include the following:

- The lack of appropriate accounting and auditing standards (46\%).

- Exposure to undue legal liability (38\%).

- Increase in audit costs (31\%).

The field of activity of the responding companies had a great influence on the above ranking of reasons. With the exception of the construction companies, the respondents agreed only on the first reason, while providing varying support for the other reasons.

\section{Summary and recommendatlons}

In this article, certain issues important to the subject of future-oriented company annual reporting were investigated from the point of view of the financial managers of the 1989 Financial Mail Top 100 companies. The results of this investigation indicate in the first instance that companies should consider disclosing future-oriented information in their annual reports. Support for such action is not only provided by the fact that $49 \%$ of the respondents were of the opinion that a need for such disclosures exists, but also by the growing body of literature directed to the subject (for example, refer to Wagner, 1983: 90; SAICA, 1989; and Adams, 1990: 6).

Secondly, the results support disclosure of the information along the lines described in the section on the presentation of future-oriented information in company annual reports. Such disclosures should be voluntary at this stage. It is believed that the practice of future-oriented company annual reporting should undergo further experimentation so that different approaches and methods of disclosure can be pursued and companies can learn from their own experiences as well as that of others.

Lastly, the results suggest that future-oriented information published in company annual reports should at this stage no be audited by a public accountant. SAICA's (1989) recommendations on the public accountant's examination and reporting duty towards profit forecasts should in the meantime be restricted to documents other than the annual report.

In conclusion it must be noted that future-oriented company annual reporting is a complicated subject requiring careful consideration of not only the above three aspects but also other related issues. More research therefore needs to be undertaken which will facilitate the identification of definitive conclusions.

Suggestions in this regard include an investigation of:

1. the decision-making process of the users of financial reports and the role of future-oriented information in this process;

2. the information content of published future-oriented information, that is, the effect the information has on the price and trading volume of shares;

3. the treatment afforded to unfavourable statements of future expectations;

4. the accuracy of published future-oriented information; and

5. the manner in which the information and revisions to it should be communicated to the users of financial information.

\section{Acknowledgement}

The author acknowledges the Research and Bursaries Committee of the University of South Africa and the Institute for Research Development of the Human Sciences Research Council for the financial assistance granted to complete the study. Opinions expressed in this publication and conclusions arrived at, are those of the author and are not necessarily to be attributed to the University of South Africa or the Institute for Research Development.

\section{Note}

This article is based on the author's thesis which was completed for the DCom degree in Accounting at the University of South Africa.

\section{References}

Adams, B.H. 1990. An accountant's vision for the year 2000. Graduation address. Johannesburg: University of the Witwatersrand, 8p.

American Institute of Certified Public Accountants (AICPA). Auditing Standards Board (ASB). 1985. Statement on standards for accountants' services on prospective financial information - Financial forecasts and projections. New York. $35 p$.

American Institute of Certified Public Accountants (AICPA). Financial Forecasts and Projections Task Force. 1986. Guide for prospective financial statements. New York, 235p.

Canadian Institute of Chartered Accountants (CICA). Accounting Standards Committee (AcSC). 1989a. Future-oriented financial information. Exposure draft. Toronto. 
Canadian Institute of Chartered Accountants (CICA). Auditing Standards Steering Committee. 1989b. Examination of a financial forecast or projection included in a prospectus or other public offering document. Auditing and related services guideline. Toronto.

Ferris, K.R. \& McDonald, B.C. 1982. 'Financial forecast disclosure: panacea or Pandora's box?' The Australian Accountant, Vol. 52: 330-335.

Howell, G.A.E. 1987. Forecast information in the financial statements of listed companies: current practice and investor

Appendix 1 Need for publishing future-oriented information in company annual reports

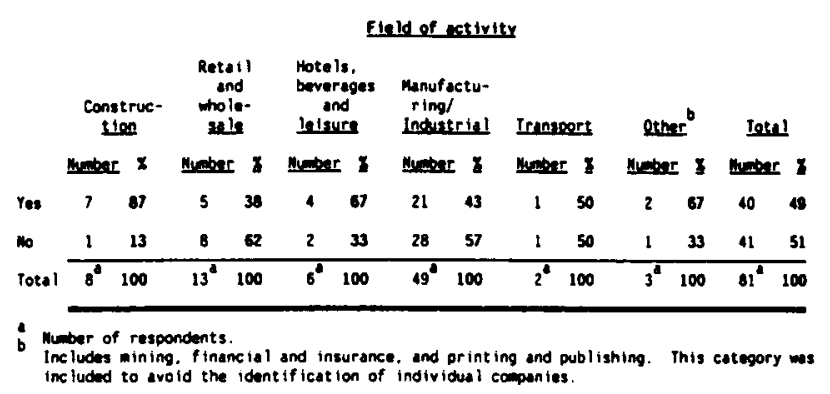

Appendix 2 Reasons why companies should disclose future-oriented information

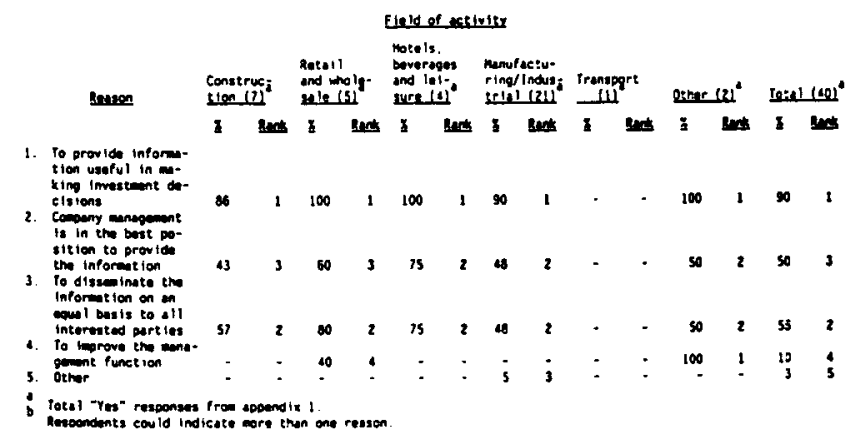

Appendix 3 Reasons why companies should not disclose future-oriented information

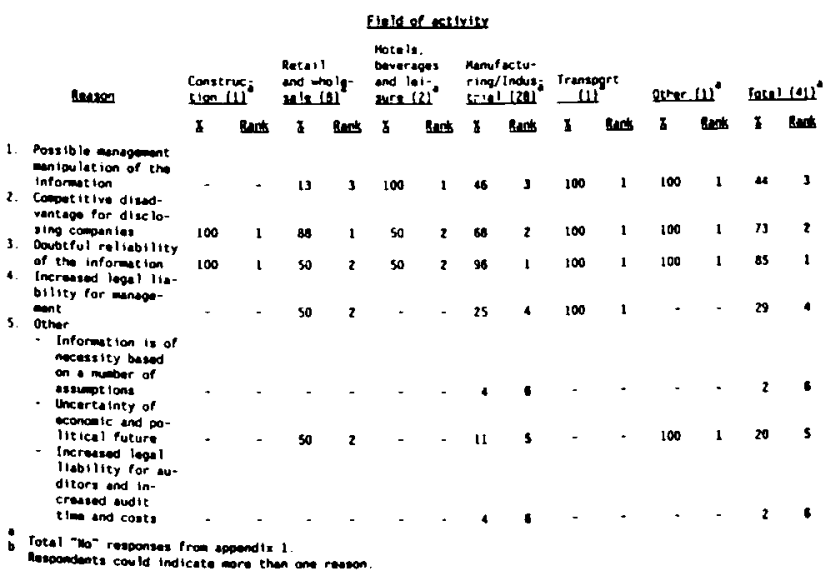

attiudes. Technical report, Cape Town: University of Cape Town, 77p.

Loe, T.A. (ed.) 1981. Developments in financial reporting. Oxford: Philip Allan, 292p.

South African Institute of Chartered Accountants (SAICA). 1989. Profu forecasts. Audit and accounting guide. Johannesburg.

Tonkin, D.J. 1989. World survey of published accounts. London: Lafferty, 524p.

Wagner, T. 1983. 'The annual report: an important corporate communications tool', The South African Chartered Accountant, Vol. 19: 90-91, 93.

Appendix 4 Presentation of future-oriented information in company annual reports

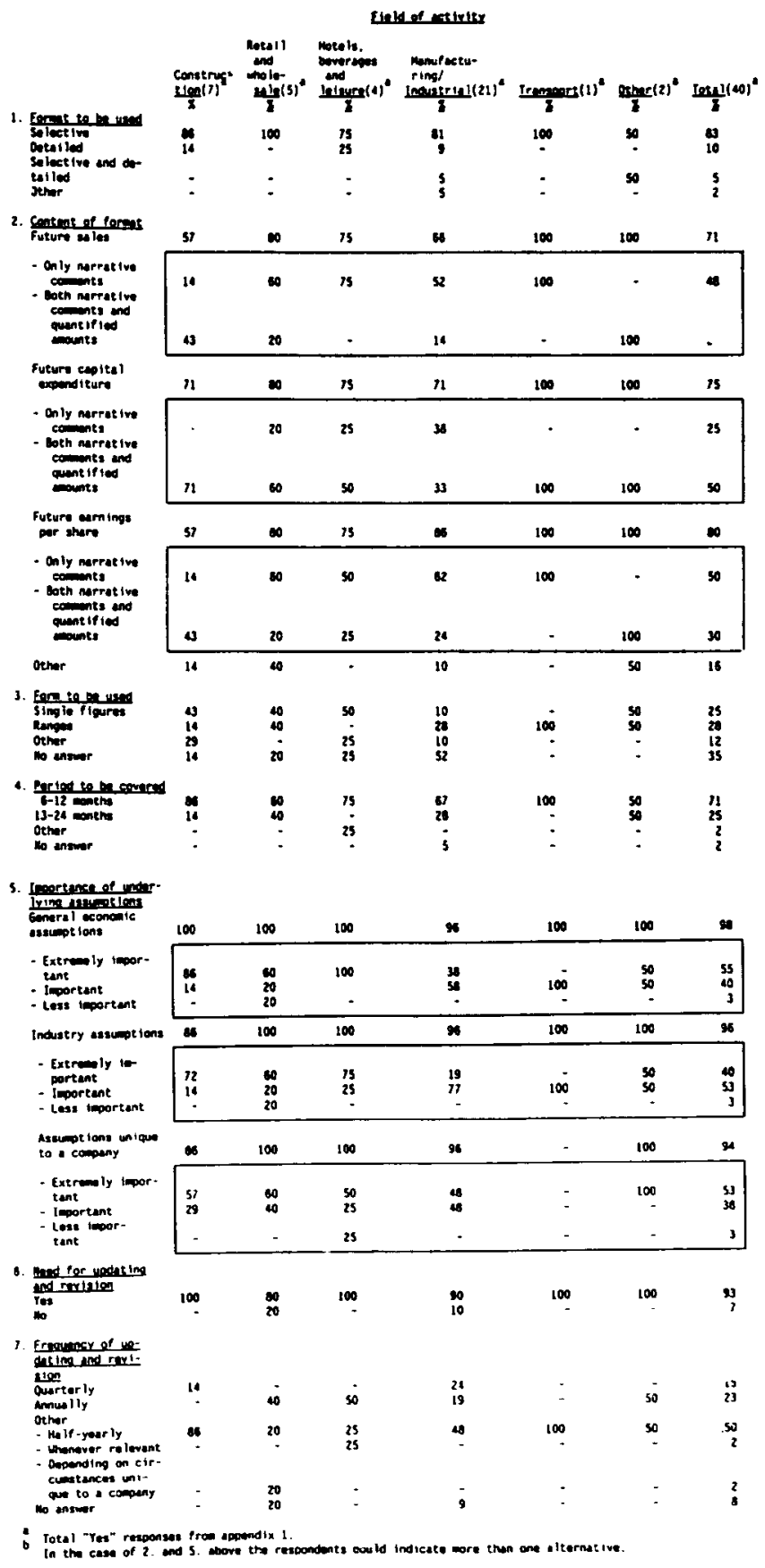


Appendix 5 Need for public accountant audit of futureoriented information published in company annual reports

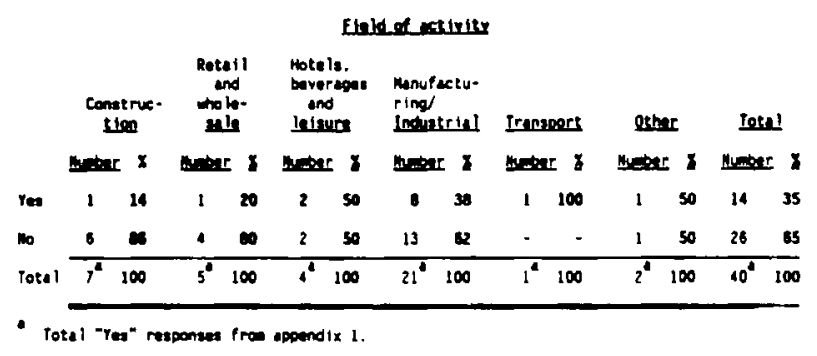

Appendix 6 Reasons why the public accountant should audit published future-oriented information

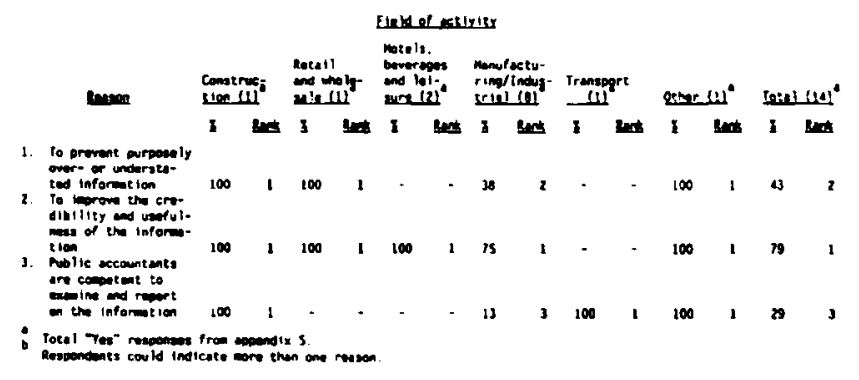

Appendix 7 Reasons why the public accountant should not audit published future-oriented information

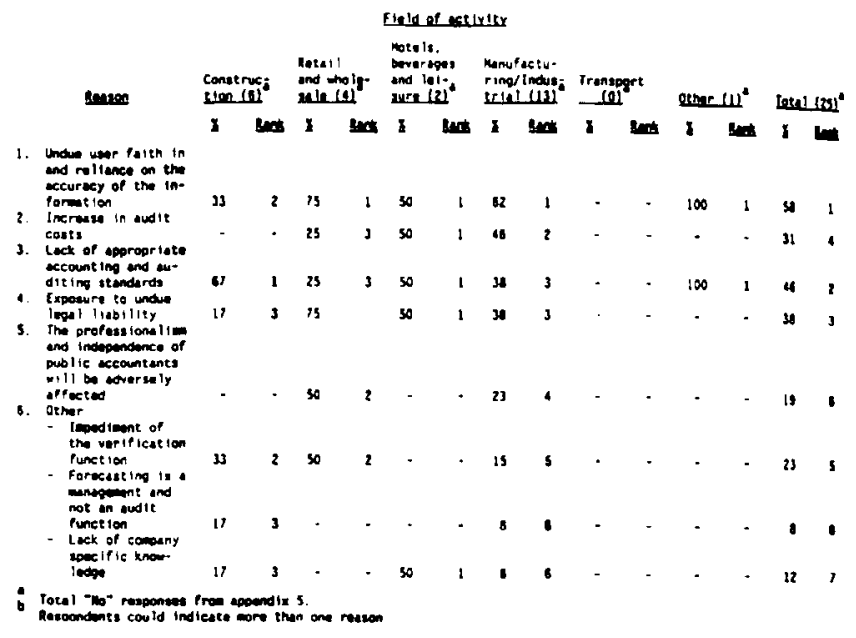

